used as long ago as 1874. The magnetite is mixed with chareoal in a special furnace and duly fired. When trade started with western Europe the local smelting nearly ceased, but the imported steel was of such a poor quality that it has all started up again. The Zambia example from a site at Mr. Strydom's farm some 8 miles from Livingstone is not dissimilar. But no mention of the kind of iron ore used is given. Smelting has been observed (Burkitt, M. C., unpublished) at Serenje, also in Zambia, but a good way north of Livingstone. Here the ore was a carbonate and hence much more easily smelted. There is plenty of interesting material in this number of Man, but the attention of all anthropologists should be especially directed to the long and sympathetic obituary of the late Lord Raglan by Prof. C. Daryll Forde.

\section{Archaeological Excavations}

A MEMORANDUM on the subject of safety precautions in archaoological excavations has been prepared by the Council of British Arehaeology. It will act as an aidemémoire to site directors and supervisors of archaeological excavations and also give valuable information to societies for whom they may be working. Copies (6d. plus postage) can be obtained from the Council of British Archaeology, 10 Bolton Gardens, London, S.W.5.

\section{The Acorn Lectures}

Volume 2 of the Acorn Lectures, delivered at the A. D. Little Research Institute, Inveresk, contains abridged versions of four lectures, namely those of Dr. C. B. Amphlett on "Inorganic Ion Exchanges"; Dr. D. W. Pashley on "Electron Microscope Studies of Thin Films"; Prof. C. E. H. Bawn on "Stereoscopic Forces in Free Radical and Ionic Polymerization"; and of Prof. R. H. Thomson on "Black Pigments" (Pp. v+51. Inveresk: Arthur D. Little Research Institute, 1964). The lectures are not dated and the volume is edited by W. Banks.

\section{Metal-to-Metal Bonds}

THE number of compounds in which metal-to-metal bonds have been shown to exist has greatly increased during the past few years. Such compounds may be divided into various classes, depending on the kind of interaction between the metal atoms which, for transition metals, may be direct or indirect, involving interaction via other atoms. Compounds of the first type show weak interaction or strong co-valent bonding, depending on the metal chosen, the oxidation state, and the attached ligands. Bonds between dissimilar transition metal atoms are less common than those between similar metal atoms, but this appears to be due to lack of purposeful effort to obtain such derivatives until recently. The extent to which co-valent, ionic, multi-centre, and indirect interaction occurs in these compounds has been discussed by Prof. J. Lewis of the University of Manchester and Prof. R. S. Nyholm of University College, London, in Science Progress $(52$, No. $208 ; 1964)$. The role of physical methods in assessing this is also reviewed.

\section{Soil Fertility and Elements of Rural Sociology in Africa South of the Sahara}

IN its participation in the campaign against hunger, the Centre de Documentation Economique et Sociale Africaine has produced a bibliography entitled Fertilité des Sols et Eléments de Sociologie Rurale en Afrique au Sud $d u$ Sahara, by J. Lebrun and P. C. Lefovre (Pp. xvii + 182. Bruxelles: Centre de Documentation Economique et Sociale Africaine, 1964. 500 francs). The object has been to collect as many as possible of the publications dealing with the soils and their fertility, especially as related to social problems, in order to assist in finding remedies for the problems concerning food production. There are 1,413 references to authors in alphabetical order, with the titles of their work, and a list of the periodicals cited. These references have also been summarized by number under various heads such as agricultural development, soils, erosion, productivity, fertilizers and sylviculture. There is a geographical index.

\section{Announcements}

Dr. W. C. Elmore, chairman of the Department of Physics and professor of physics at Swarthmore College, Dr. F. Verbrugge, associate Dean of the Institute of Technology and professor of physics at the University of Minnesota, and Dr. L. R. Weber, department head and professor of physics at Colorado State University, have received distinguished service citations from the American Association of Physics Teachers, for their outstanding contributions to the teaching of physics in colleges and schools.

IN No. 789 in the Science Library Bibliographical Series some references to hovercraft from 1959 to 1964 are collected, both from books and periodicals, as well as reports and British patents specifications (Pp. 13. London: The Science Museum, 1964).

A symposium on "Pump Design, Testing and Operation" will be held at the National Engineering Laboratory during April 12-14. Further information can be obtained from the Organizing Secretary, Pump Symposium, National Engineering Laboratory, East Kilbride, Glasgow.

A GENeral discussion of the Faraday Society on "The Kinetics of Proton Transfer Processes" will be held in the University of Newcastle upon Tyne during April 12-14. Further information can be obtained from the Assistant Secretary, the Faraday Society, 6 Gray's Inn Square, London, W.C.1.

The first meeting of the Environmental Group will be held in the Imperial College of Science and Technology on April 9. Dr. Chrenko will address the meeting on the subject of "Freshness". Further information can be obtained from the Secretary, the Environmental Group, 16 Gloucester Place, London, W.1.

THE spring meeting of the British Society of Rheology on "The Flow of Powders and Granular Materials" will be held in Nottingham during April 7-8. Further information can be obtained from Mr. R. J. Cole, British Society of Rheology, Paint Research Station, Waldegrave Road, Teddington, Middlesex.

THE spring conference of the X-ray Analysis Group of the Institute of Physics and the Physical Society will be held in the University of Edinburgh during April 8-9. Further information can be obtained from the Administration Assistant, Institute of Physics and the Physical Society, 47 Belgrave Square, London, S.W.1.

A sxmposium on "Microbiological Deterioration in the Tropics", arranged by the Microbiology Group of the Society of Chemical Industry, will be held in London during April 8-9. Further information can be obtained from the Honorary Secretary, Society of Chemical Industry, 14 Belgrave Square, London, S.W.1.

A CONFERENCE on "Atomic Spectra and Radiation Processes", arranged by the Institute of Physics and the Physical Society, will be held in the Clarendon Laboratory, Oxford, during April 12-14. Further information can be obtained from the Administration Assistant, the Institute of Physics and the Physical Society, 47 Belgrave Square, London, S.W.1.

A Residential conference on "The Educational Requirements for the Professional Inspection and Quality Engineer", arranged by the Institution of Engineering Inspection, will be held at the Chelsea College of Science and Technology during April 11-14. Further information can be obtained from the Secretary, Institution of Engineering Inspection, 616 Grand Buildings, Trafalgar Square, London, W.C.2. 